International Research Journal of Management, IT \& Social Sciences
Available online at https://sloap.org/journals/index.php/irjmis/
Vol. 7 No. 1, January 2020, pages: 72-83
ISSN: 2395-7492
https://doi.org/10.21744/irjmis.v7n1.825

\title{
Prezi as an Innovative Teaching Tool for the Strengthening of Significant Learning
}

\author{
Paola Katherine Moreira Sanchez ${ }^{\text {a }}$ \\ Marcos Fernando Pazmino ${ }^{b}$ \\ Maria Rodriguez Gamez ${ }^{c}$
}

Article history:

Submitted: 09 November 2019

Revised: 18 December 2019

Accepted: 03 January 2020

Keywords:

educating;

innovative didactic tools;

pedagogy;

significant learning;

technology;

\begin{abstract}
The purpose of this research is to determine the implementation of innovative teaching tools, for the strengthening of significant learning, applied by teachers, in the teaching-learning process. By using innovative resources, it allows students to orient and build knowledge in all disciplines, the use of Prezi pursues, that learning is meaningful, the purpose of study is focused on analyzing the use of innovative teaching tools in the teaching process, through observation and survey techniques, in order to improve learning, it was also possible to detect that the origin of the problem is the low use of the application of innovative digital tools that serve as support in the planning of the different subjects in a creative and interactive way in the process. In this sense, teachers who teach in the upper basin of the Educational Unit "Costa Azul" of the city of Manta, Ecuador, have been considered as object of study, the methodology applied is focused on the scientific, inductive and deductive method planning a direct observation in the fieldwork, considering the prevalence of innovative teaching strategies that allow fostering a pedagogical process thus avoiding traditional methods and prioritizing meaningful and autonomous learning that achieves the purpose of demanding academic training in the educational field.
\end{abstract}

International research journal of management, IT and social sciences (C) 2020. This is an open access article under the CC BY-NC-ND license (https://creativecommons.org/licenses/by-nc-nd/4.0/).

\section{Corresponding author:}

Maria Rodriguez Gamez,

Pontificia Universidad Católica del Ecuador Sede Manabí, Portoviejo, Ecuador.

Email address: mrodriguez@pucem.edu.ec

\footnotetext{
Pontificia Universidad Católica del Ecuador Sede Manabí, Portoviejo, Ecuador

b Universidad Técnica de Manabí, Portoviejo, Ecuador, https://orcid.org/0000-0002-9534-2059

${ }^{c}$ Pontificia Universidad Católica del Ecuador Sede Manabí, Portoviejo, Ecuador, https://orcid.org/0000-0003-3178-0946
} 
1 Introduction

Significant learning is a process of acquiring knowledge, through the development of skills, attitudes, and dexterity in which the main protagonist is the student, who builds learning by making it part of the cognitive, dynamic and selfcritical scheme. Therefore, it is necessary to apply pedagogical strategies that help improve educational praxis in order to use innovative teaching tools to improve academic performance.

The book of the PUPC Educational Services and Research Center (2015), indicates that teacher training in education services are aimed at developing student competencies and skills, learning from Finland's best experience practices that are focused on innovative tools to the professional development of the student and specifically to innovation for teaching and meaningful learning.

People learn in a meaningful way, when they find meaning in experiences that impact them, such as new innovative learning models, using pedagogical didactic tools such as formative teaching strategies, which lead to education to new changes and transformation, in which the teacher must provide fundamental information to the student, to strengthen the skills through the use of teaching and learning methods, which support the self-realization of knowledge.

According to Vivas (2015), the University of the Balearic Islands, Illes Balears, Spain refers to countries such as Mexico, Venezuela, Argentina, England, Norway, Scotland, Romania, Philippines, China, Japan, among others, currently, in schools, they apply practices based on the Multiple Intelligence Theory (TIM), applied to the reality of the educational policies themselves and to the intellectual diversity, which lives the reality of each institution.

Gardner's TIM theories have influenced the philosophy of education, as didactic methods improving educational quality, it is also said that multiple intelligences, is a thinking model that analyzes information in a neutral way in the teaching and learning process, respecting diversity and facilitating educational inclusion.

The authors Caira et al. (2014), through constructivist-oriented education, state that in today's world teachers face new challenges, taking into account pedagogical strategies according to the needs of the student, to strengthen and energize the knowledge in the classroom, being necessary to know in depth the incidence of applications according to the level of student performance; This not only in terms of learning and academic performance but also in skills, motivation, perspective and personal achievement, among others. Therefore, it is necessary that the student has vast referential knowledge.

For Perdomo (2016), of the University Corporation Minutos de Dios, it indicates that the teacher must innovate the learning practices, taking as a fundamental axis techniques, strategies and opportune instruments that allow him to incentivize the knowledge, through the innovative practices the same that seek to reverse the roles and functions of the traditional classroom, where the classes are carried out in an active and participatory way from the development of the activities, is necessary to raise awareness that the teacher is who should be the main driver and motivator of learning in students, promoting creativity, critical, analytical and reflective thinking that leads to a solution of social reality problems.

According to Bautista (2016), from the Pontifical Catholic University of Ecuador (PUCE), based in Esmeralda, he says that the proper use of innovative tools, favors learning, contributing to an education of quality, warmth, and efficiency, allowing integral development, generating changes that impact the student's life, turning the contents into meaningful learning experiences.

By using innovative tools, it allows the teacher to establish new knowledge, improving the academic quality of an obsolete educational system autonomously, when using didactic applications in the classroom, aims to take a look at the trends that lead to thinking, analyzing and reflecting on the modalities that they plan to give answers, showing significant learning from of the implementation and application of didactic tools, in which the learning in the classroom is more dynamic and significant.

Applying innovative tools helps provide solutions to pedagogical-didactic problems and thereby improve the quality of education in the social environment, where the study determines how feasible it is to use tools that strengthen and help boost student learning based on experience and observation (León, 2012; Sanchez et al., 2019).

A determining factor at the time of the consolidation of the teaching and learning process, the teacher must renew the pedagogical practices, directing the individual to new trends, to avoid the failure or negative judgment on the intellectual capacity, allowing to stimulate learning and know the skills, attitudes, and norms in the student.

At present, the teaching-learning process is developed under a construction process, in which the student is not limited to acquiring knowledge, which allows him to be the protagonists themselves appropriating the contents in an appropriate way, capable of contributing and give creative solutions to the problems they face, based on educational experiences (Moreira, 2019; Menéndez \& Martinez, 2019).

Sanchez, PKM, Pazmino, MF, \& Gamez, MR (2020). Prezi as an innovative teaching tool for the strengthening of significant learning. International Research Journal of Management, IT and Social Sciences, 7 (1), 72-83. 
Thinking about new educational experiences, enable teachers to achieve teaching and learning, motivating the student to innovation by putting creativity into operation in the knowledge acquisition process allowing them to obtain satisfactory results.

Critical Thinking, both teacher and student, is part of the educational processes, allowing the human being to analyze, understand and evaluate. Critical pedagogy favors the application in the classroom, improving activities and turning them into innovative methods, which seeks educational models focused on students, transforming daily life and solving problems complementing their desire to overcome (Lopez, 2019; Delgado et al., 2019).

Critical pedagogy is related to the active participation of the individual, to the development of skills, to have their own self-esteem, promoting dialogue and motivating the student to learn and develop inside and outside the classroom, in a critical and reflexive manner, always interacting with the rest.

Meaningful learning and technological tools facilitate access to information and to the completion of homework and the intellectual development of the contents through procedures such as methods, techniques, and resources necessary to acquire critical thinking while allowing tools to facilitate learning. López et al. (2019), critical thinking allows us to understand how to improve the development of cognitive quality, and then interact in the classroom based on knowledge.

The work studied aims to analyze the implementation of innovative teaching tools, to improve the type of learning in the student, which strengthens meaningful learning, applying the inductive-deductive and descriptive method in the research process in the Educational Unit "Costa Azul" from the city of Manta, using innovative pedagogical models that help the teaching-learning process in an interactive and organized way.

\section{Materials and Methods}

The methodological process used in this research is inductive, deductive and descriptive, allowing to represent the current situation in the development of learning, in addition, the technique of observation, field and bibliography was applied, which gives way to establish pedagogical strategies As is the use of innovative tools, surveys were conducted on teachers and students.

\section{Results and Discussions}

There are didactic tools that allow scientific results, where students reach more rapidly the knowledge provided by teachers, being able to reach the objectives set according to the type of learning.

Types of learning

Meaningful learning

in the teaching task has the complexity involved in the selection process, evidencing what the student has learned, as well as the challenges involved in evaluating the knowledge acquired, highlighting three aspects necessary in integrative teaching, Self-evaluation and coevolution (Salazar, 2018).

It is a process of acquiring knowledge that is obtained, through cognitive skills, attitudes, and values, through which the student builds his or her own knowledge, through lived experience, resulting in the enrichment and transformation of the information received., and then act and develop it in the educational, social and cultural fields.

\section{Learning theories}

These theories are what describe the teaching process, they also help control the behavior of human beings, through skills, abilities and the creation of strategies that contribute to the strengthening of knowledge, trying to explain how an individual acquires the necessary information.

The learning, in the human being, acts under the true knowledge, that is born from the interrelation between the new information material, are connected with the pre-existing ideas in the cognitive structure, which allows a connection in time, the new and the existing idea, as a result, significant learning arises (Ausubel, 2002; Delgado et al., 2019). 
The acquisition and retention of information, knowledge are activities that are present throughout life, are a reality of effective management and improvement of the daily work of the teacher and social entity that is in the student's environment.

\section{Constructivist theory}

It is a theory of learning, based on experiences, where different perspectives and interpretations of reality are developed, the central idea of constructivism is that knowledge in the student must be active and participatory, instead of remaining in shape. Passive, that is why people need to learn when they can control learning.

Learning is a pedagogical current, where the student builds their own knowledge, to solve problematic situations through ideas, collaborative processes, reflection, and critical thinking. The constructivist aims to have the student build his own knowledge, according to Tama \& Brook (2002), he states that the educator, has the role of a mediator should support the student to; teach to think; Teach about thinking and teach on the basis of thinking.

One of the referents of this theory is Piaget, who said that learning is focused through two thoughts, assimilation and accommodation, which allows the individual to adapt to the environment and transform their own structure; likewise, it has more expectations in the field of pedagogy and in the educational field. The constructivist theory refers that learning in individuals influences cognitive development, in addition to thinking processes related to the product of mental construction (Saldarriega et al., 2016).

Constructivist teaching stimulates the student, to interpret the development and derivation of convergent points, to organize and guide the information and at the same time, it fosters educational practices according to the complexity in the different stages, seen as the process, based on the experiences that are incorporated into the new knowledge, which act on a mental scheme.

\section{Theory connectivity evolution}

The era of technology and evolution in the teaching-learning process have changed the new ways of approaching educational processes, in relation to the knowledge society, both children and young people have contacts with digital environments and their links interpersonal relationships, through social networks, which develops ways of thinking, how to see and understand why the teacher must generate significant changes in educational practices (Solorzano \& García, 2014).

According to digital development, learning is transformed to technological needs; connectivism is a learning theory that was promoted by Stephen was called the learning theory for the digital age, it explains the complexity of knowledge in a fast-evolving analog social world, where students recognize and interpret various content in networks, taking strength of connection and own learning in virtual environments.

\section{Teaching tools}

Currently, in education, educational resources should be used, which should be used by the educator, to improve educational practices, which are essential to strengthen the skills and abilities of the student. The teacher must be prepared, for changes and transformation to new forms of teaching, leaving aside traditional practices, following the trends that they will favor when planning and developing skills and competencies in a creative and interactive way teacher as a student (Tinoco \& Tinoco, 2017).

A didactic tool is a resource or materials that allows the educator to facilitate the teaching process, as well as helping to carry out daily activities in the classroom, allowing the student to perform collaborative work, in an integral way, achieving quality in the learning, being necessary for the teacher to know and incorporate applications that improve the educational process.

\section{Computer and communication techniques as a didactic tool}

In the teaching-learning processes, the new trends in information and communication technology (tick) are parallel, incorporating them into the educational field, gaining more and more space in the different academic environments, serving as support for the subject plans, based on the use of teaching tools, transversal projects, and teaching strategies, creating new methods and structures that involve the student in the construction and consolidation of knowledge,

Sanchez, PKM, Pazmino, MF, \& Gamez, MR (2020). Prezi as an innovative teaching tool for the strengthening of significant learning. International Research Journal of Management, IT and Social Sciences, 7 (1), $72-83$. 
allowing the analysis of aspects of society, developing cognitive abilities that allow analyzing and reflecting giving solutions to problems according to (Baños et al., 2018).

The technologies are part of the educational social process, they are made up of programs and tools that facilitate the development of learning, through the connection of technological, administrative support, which is shared in the search for online resources, providing human development to face life problems that help in strengthening communication.

The tics, as a teaching strategy, facilitate the development of the abilities of an individual, in order to properly perform a task, having multiple reasons to take advantage of the possibilities of the new educational paradigm, keeping the student activities in a personalized way, improving the productivity aimed at the development of competencies and the transformations of innovation that determine the dynamics and participation of multiple intelligences (Delgado, 2017).

By promoting the tics, in the education process, it creates participatory and creative students with positive attitudes, with adequate management of multimedia resources such as teaching tools, interactive videos, audio, and images, turning the dynamic and interesting class with favorable results reaching learning significantly.

\section{Digital tools to strengthen learning}

These are instruments that favor the search for information on any subject, serving the student as a help, contributing to the accomplishment of tasks and cognitive development. The teacher applies digital platforms in real-time sharing documents to assign activities, improving the work process in a creative and collaborative way through the internet, with the help of new technologies. Figure 1 shows the concept map that the teacher uses to achieve the introduction of digital technologies in the learning process.

a) Pixton is a tool that teachers or students can use to dynamically interactivity in the classroom, allowing content to be created that combines the linguistic and visual part.

b) Rubistar is an application that serves the teacher to make evaluation rubrics easily in a short time.

c) Pow Toon is an online animation application that allows the user to create an animation is animated with predetermined object, images and sounds.

d) Edmodo is an educational platform that allows sharing documents and information and communication in private mode or social network mode.

e) Symphonic It is a virtual calendar as a blackboard you can add or manage tasks through multimedia sticky notes, allowing editing between groups established for chatting or videoconferencing.

f) Mind Master It is a tool that offers users a good experience in the exploration of brainstorming. Mind maps can be made that helps to stimulate learning.

g) Prezi is a multimedia application for creating presentations similar to Microsoft Office PowerPoint.

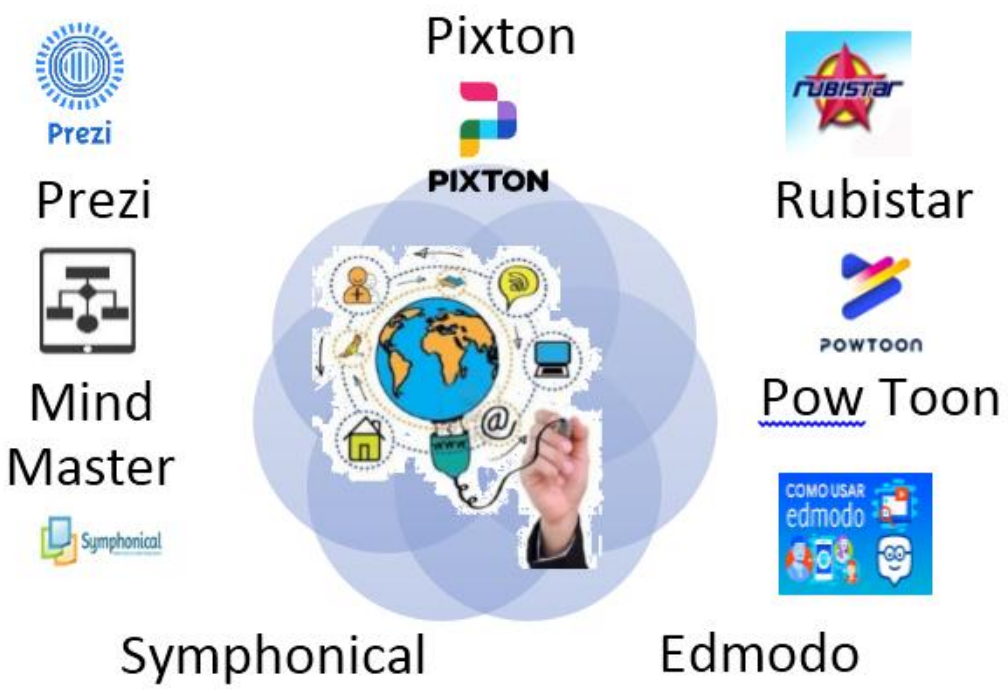

Figure 1. Digital tools 
Once analyzed each of them, it is necessary to know the usefulness of the Prezi application, as a didactic tool for the strengthening of significant learning within the educational field.

\section{The Prezi as a technological innovation}

In the case of the Prezi tool, it is simple, it offers the same characteristics as the PowerPoint, differentiating it from any other program when it is shown as a canvas unlike traditional slides, the use of this innovation allows the exhibition It is done in a short period of time, showing images to be observed throughout the presentation, editing according to the selected order, such as images, videos, audios, animations, links, thanks to the creation of the teacher put into practice their creativity.

In the process of academic training, the Prezi can enforce the objectives, goals and strategies of the students, as well as in the development of skills efficiently and effectively; however, educational units require management that contributes with the participation of teachers-students and parents with responsibility, creating innovative tools that organize and guide information in a natural way (Gómez, 2014).

\section{Prezi application pathprezi}

When is created, the beneficiary can choose from a range of preset templates, reused templates and if he prefers a blank canvas; In addition, the user can publish and display the presentation according to their needs, this application has an intelligent structure, revelation with zoom, freedom of movement among others.

Template: The user chooses among a series of options according to the needs, they can modify the presentations of the different topics such as history, economics, sport, technology, computer science, all in order to personalize the canvas, once chosen a default form, proceed to write the name of the document with which the Prezi will be identified.

Customize: You can use the automatic assistant, this tool can set options for Prezi library fonts, in addition to customizing the colors of the canvas and companies can add the exact colors of their brand.

Backgrounds and transformation: the tool is a fundamental instrument of the canvas, once the presentation appears it is clicked allowing to move, increase the size and rotate the content.

Frames: It is located in the upper left corner (frame frames), from this place you can choose: add, insert, circles, rectangles, mark all this invisible in order to frame the information on the canvas as desired by the user.

Images: when you insert the image, you have two alternatives, the first one to type a keyword from the Google search engine, then drag the object to the desired position, the second one to access the files that are saved from your computer or device, through the File button, select the file, then insert in the place we want.

Symbols and form: allows the implementation and subdivision in several styles such as photographic, simple dark, simply white, drawn, precious, stickers, shapes.

My contents: It is a space to store the forms and to use more frequently there are two options: the first favorites and the second since Prezi.

Design: It allows to organize the content, in images or text, it has two sub-divided, the first single frames and the second multiple frames this option allows to insert diagrams and diagram, in the text of the diagram can be written, there are pre-designed figures allowing the user Organize the ideas.

Draw line or arrow: This application allows lines or arrows of different colors, to connect, point to one or different canvases, pressing left click to scroll smoothly to link the elements.

Add speech: You can add to the presentation speech during development according to the needs.

Add music: You can add background music or instrumental song to play during the presentation according to the theme you want to develop.

YouTube videos: This icon provides a sub-window to insert the uniform resource locator URL. (Uniform resource locator) to identify the exact video from the YouTube platform, allowing videos to be inserted and moving anywhere on the canvas.

From File (pdf, video), you can upload files, videos or documents, from the computer joining the canvas as needed. PowerPoint: File can be uploaded from the computer to incorporate them into the canvas so that the user will use it according to the priority.

Sanchez, PKM, Pazmino, MF, \& Gamez, MR (2020). Prezi as an innovative teaching tool for the strengthening of significant learning. International Research Journal of Management, IT and Social Sciences, 7 (1), $72-83$. https://doi.org/10.21744/irjmis.v7n1.825 


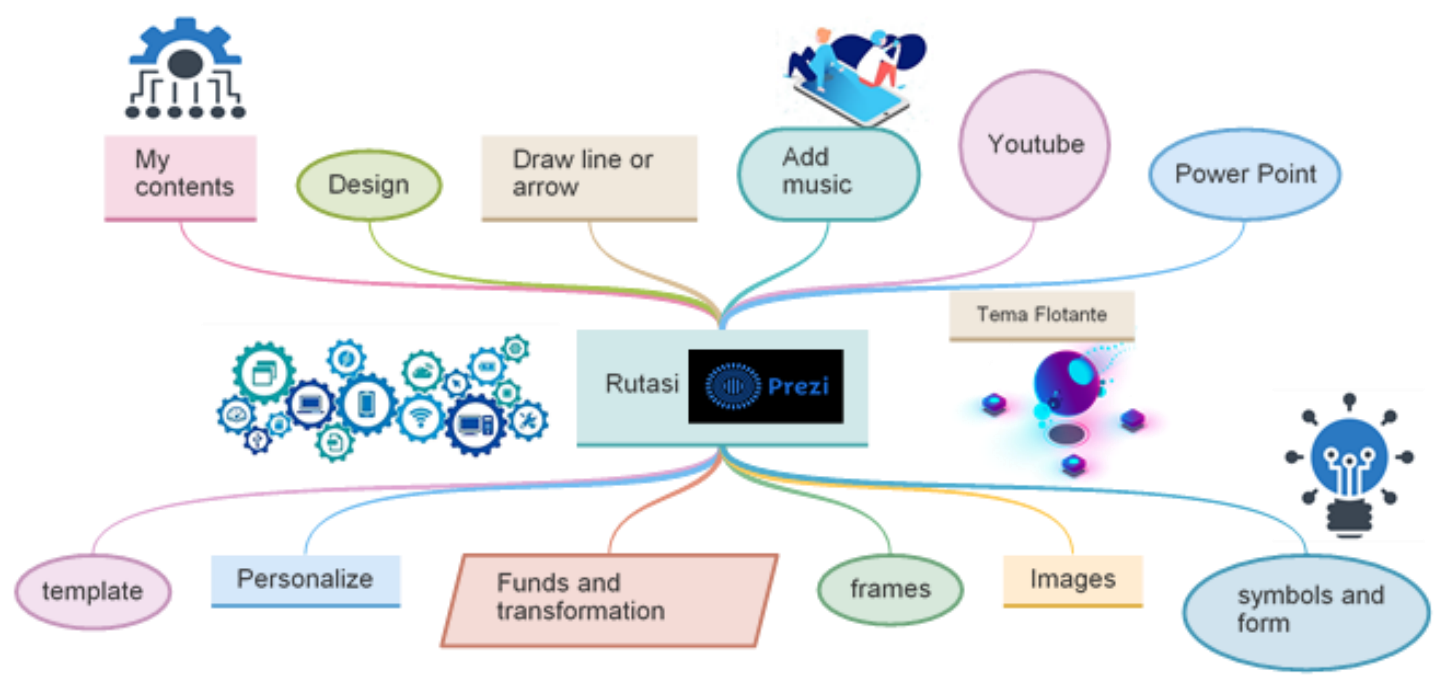

Figure 2. Route of the Prezi

Each of them fulfill their functions, allowing to develop through the sequence and order of logical escalation, following with three stages: teaching to know, process, and reason, the first allows to explore the different stages of life, continuing with the information process and finally reasoning about the operation, of the application of digital tools, which help to solve everyday situations in a simple way by applying Prezi as a pedagogical support tool.

In order to know if the Prezi tools meet their teacher-student objective, a survey of a 200 population involved was carried out, selecting the sample from the methodology applied by Larry Murries using equation (1).

$$
n=\frac{z^{2} p q N}{N e^{2}+z^{2} p q}
$$

$\mathrm{n} \rightarrow$ Sample size (?)

$\mathrm{z} \rightarrow$ Confidence level (1.96)

$\mathrm{p} \rightarrow$ occurrence probability $(0.5)$

$\mathrm{q} \rightarrow$ non-occurrence probability $(0.5)$

$\mathrm{N} \rightarrow$ population or universe (200)

$\mathrm{e} \rightarrow$ acceptable limit or sample error $5 \%(0.05)$

Obtained that the sample $\mathrm{n}=80$

One of the results obtained in the use of innovative tools in teachers allowed to know the handling of the subjects of study when using technological resources for its conception as a means of promoting both collaborative and autonomous learning, as well as recovering the perception of the development of competences from its use.

In Figure 3, it can be shown that $76 \%$ of teachers use technological resources, favoring the teaching-learning process, demonstrating that they are used in the classroom, for the strengthening of autonomous learning, promoting interaction, as well as the development of competence. 


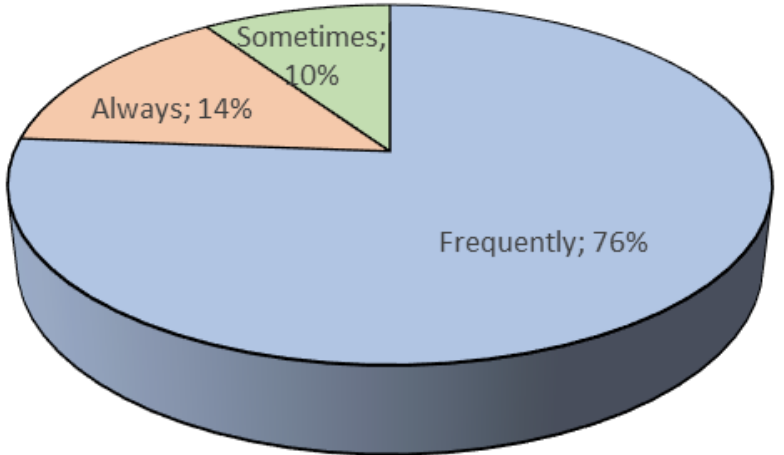

Figure 3. Uses of technological resources help meaningful learning

When interviewing the students of the Educational Unit "Costa Azul", they expressed that it was related to the usefulness of the use of Tics tools by the teacher for the development of the subject to strengthen learning, it shows as shown in figure 2, according to the data obtained that $45 \%$ of teachers use the tics in the process of the subjects they teach, facilitating collaborative and didactic learning with advantages for students, Compared to the answer, they are used in an optional way, allowing autonomous work in the students, sharing information during the development of the subject.

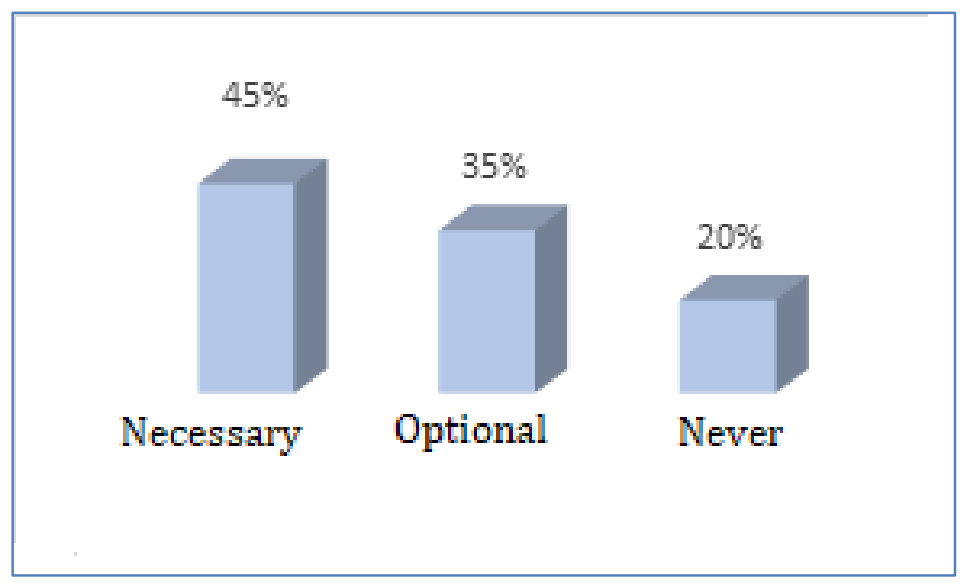

Figure 4. Teachers who use ICT tools as pedagogical support in the subjects

According to respondents as indicated in Figure 5, 50\% and 60\% almost always use technology as didactic support for performing tasks creatively, and always use technology for communication with other people, and sometimes use the technology to perform to theorize knowledge.

Sanchez, PKM, Pazmino, MF, \& Gamez, MR (2020). Prezi as an innovative teaching tool for the strengthening of significant learning. International Research Journal of Management, IT and Social Sciences, 7 (1), $72-83$. https://doi.org/10.21744/irjmis.v7n1.825 


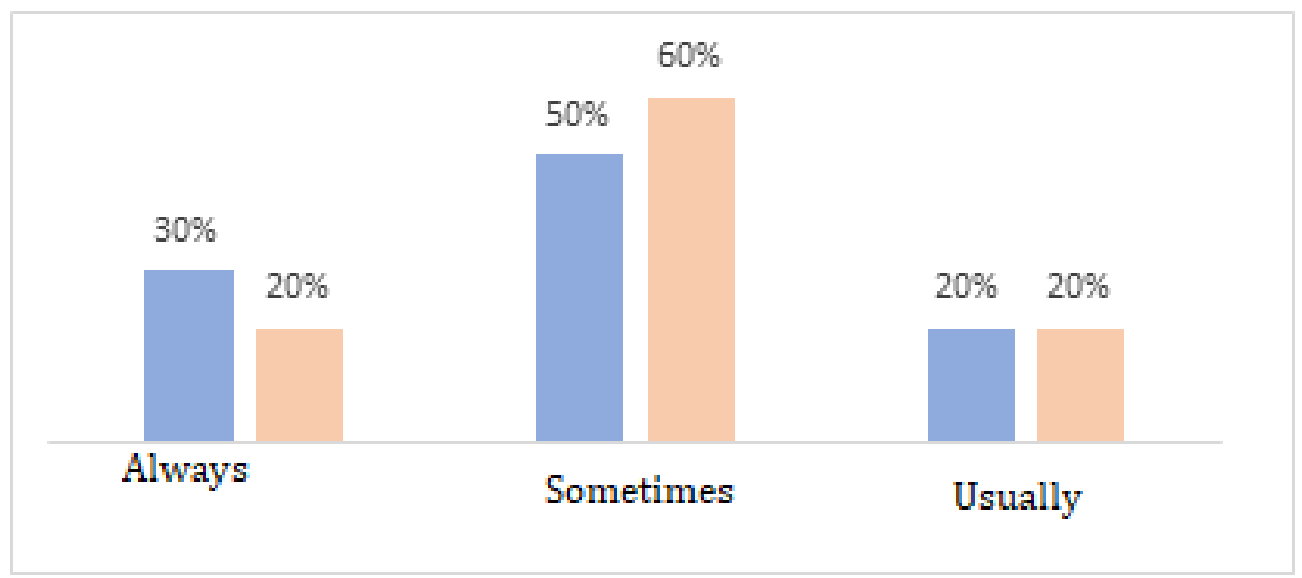

Figure 5. Use of tools for the accomplishment of homework

When consulting the teacher, they expressed that some of them use applications as pedagogical support for strengthening learning, obtaining a result in Figure 5, on the use of digital tools stating that the majority of teachers and students use $30 \%$ PowerPoint in the teaching-learning process allowing the creativity of pedagogical activities; continuing with the Prezi that give it a good use to achieve a presentation in an orderly way that allows the interactive and dynamic class, by using Mind Master you can work collaboratively and creatively, following with other digital tools such as Pixton, Pow Toon, Edmodo, which has a good use serving as support within the educational process for the development of learning. When consulting the teacher, they expressed that some of them use applications as pedagogical support to strengthen learning.

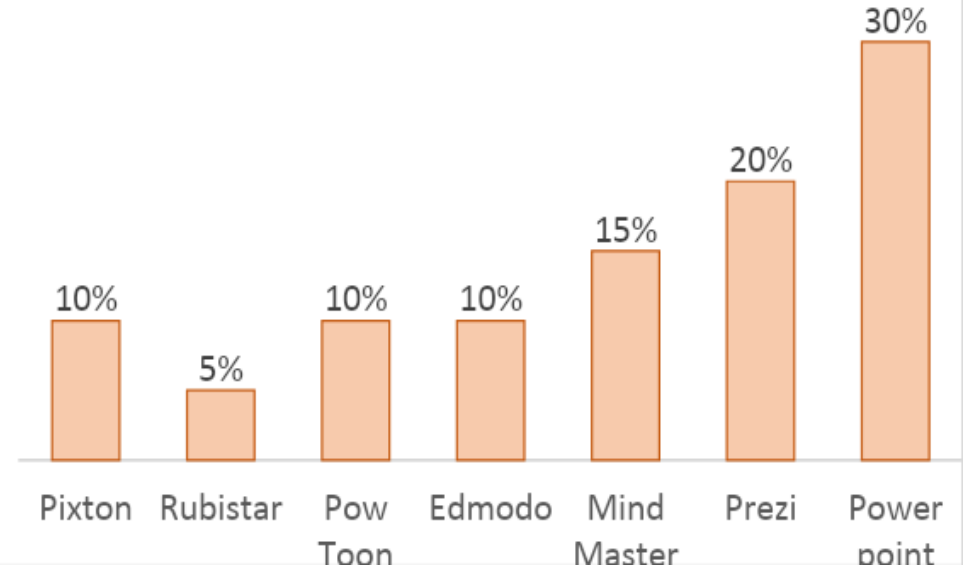

Figure 6. About the application which one they use as pedagogical support when they teach

education has faced new learning challenges where didactic environments play a necessary role during student life, both academically and personally, it also allows to work individually and autonomously or in a collaborative team, the study of research, It seeks the implementation of digital tools, which lead to the orientation and construction of knowledge, in all disciplines, the use of Prezi pursues, that learning is meaningful.

\section{Conclusion}

The use of technology and innovation, has the purpose of changing traditional practices, to develop a creative and constructive knowledge in the realization of a task taking into account the communication and information tools linked 
to the Prezi itself that will develop skills and dexterity in the domain of this presentation software that help improve meaningful learning, such as challenges of a complex virtual world.

$76 \%$ of teachers said that the use of technology is often necessary for meaningful learning, as well as the surveyed students assumed in $30 \%$ the utility they use in-class activities at PowerPoint, therefore, it is evident that the application of the Prezi is an innovative proposal with an orderly, creative and interactive presentation for the achievement of learning.

\section{Conflict of interest statement}

The authors declared that they have no competing interests.

Statement of authorship

The authors have a responsibility for the conception and design of the study. The authors have approved the final article.

\section{Acknowledgments}

The authors would like to thank the reviewer for their consideration of the further process of the present paper. Thanks to the editor of IRJMIS for the valuable support, time as well as advice.

Sanchez, PKM, Pazmino, MF, \& Gamez, MR (2020). Prezi as an innovative teaching tool for the strengthening of significant learning. International Research Journal of Management, IT and Social Sciences, 7 (1), $72-83$. https://doi.org/10.21744/irjmis.v7n1.825 


\section{References}

Ausubel, D. (2002). Acquisition and retention of knowledge a cognitive perspective (Vol. 1). Barcelona: Printed in Spain

Obtenido

https://books.google.com.ec/books?id=VufcU8hc5sYC\&printsec=frontcover\&dq=\#v=onepage\&q=a\%C3\%B1o $\& \mathrm{f}=$ false

Baños, M., Lezcano, F., \& Casado, R. (2018). Materiales multimedia: Diseño desde una pedagogía inclusiva, Universidad de Burgos España. Eur.J Develop. Educa. Psychop, 6(2), 107-118. Obtenido de https://dialnet.unirioja.es > descarga > articulo

Bautista, C. (2016). Analisis de la importancia de las tic en el fortalecimiento del aprendizaje significativo en los niños de primer año de educaciòn basica de la Unidad Educativa San Jose Benito Cottolengo en el año 2016, Pontificia Universidd Catolica del Ecuador, Esmerald. Obtenido de https://repositorio.pucese.edu.ec/bitstream/123456789/927/1/BAUTISTA\%20BODERO\%20CARMEN\%20.pdf

Caira, J., Urdaneta, E., \& Mata, L. (2014). Estrategias para el aprendizaje significativo de procesos de fabricaciòn mediante orientacòn construtivista, Universidad del Zulia; Maracaibo, Venezuela. 30(75), 92-103. Obtenido de https://www.redalyc.org/pdf/310/31035400006.pdf

Delgado, J. L. D., Bone, Y. I. E. B., Lascano, M. A. G. L., \& España, S. G. G. E. (2019). Dyslexia as learning problem and its pedagogical intervention. International Journal of Health Sciences, 3(3), 1-7. https://doi.org/10.29332/ijhs.v3n3.333

Delgado, M. A. C., Delgado, R. I. Z., Palma, R. P., \& Moya, M. E. (2019). Dyscalculia and pedagogical intervention. International Research Journal of Management, IT and Social Sciences, 6(5), 95-100. https://doi.org/10.21744/irjmis.v6n5.710

Delgado, Z. (2017). Analisis del uso de las tic como herramientas fundamental para fortalecer el proceso de enseñanza-aprendizaje en los estudiantes de la básica superior de la Escuela Camilo Borja durante el año 2016 2017, (tesis de maestria) Pontificia Universidad Católi. Obtenido de https://repositorio.pucese.edu.ec/handle/123456789/1105

Gómez, M. (2014). El material didáctico expuesto en clase como instrumento de educación para la paz, Universidad Autónoma del Estado de México,. Paz y Conflicto, 1(7), 155-174. Obtenido de https://dialnet.unirioja.es > descarga > articulo

León-Yánez, S. (Ed.). (2012). Red book of endemic plants of Ecuador. Herbarium QCA, Pontifical Catholic University of Ecuador.

Lopez, M. (2019). La pedagogia crítica como propuesta innovadora para el aprendizaje significativo en la educación básica. Rehuso, 4(6), 87-08. Obtenido de https://revistas.utm.edu.ec > index.php > Rehuso > article > download

López-Borrull, A., Ollé-Castellà, C., Abadal, E., \& Garcia-Grimau, F. (2019). Plan S: Oportunidades y amenazas para las revistas de Humanidades y Ciencias Sociales. CRECS. Recuperado de https://tinyurl. com/yy456f42.

Menéndez, E. S., \& Martinez, M. E. M. (2019). Problems of learning and pedagogical intervention. International Journal of Social Sciences and Humanities, 3(2), 105-111. https://doi.org/10.29332/ijssh.v3n2.301

Moreira, P. (2019). Las tic en el aprendizaje significativo y su rol en el desarrollo cognitivo de los adolescentes. ReHuSo, 1-12. Obtenido de https://revistas.utm.edu.ec > index.php > Rehuso > article > download

Perdomo, W. (2016). Estudio de evidencias de aprendizaje significativo en un aula bajo modelos Flipped Classroom, Corporación Universitaria Minuto de Dios. EDUTEC, 1(55), 1-17. Obtenido de https://www.edutec.es > revista > index.php > edutec-e > article > view

PUPC. (2015). Universidad en la formaciòn de formadores pedagògicos para la innovaciòn en el aula. lima-perù: $\begin{array}{llll}\text { Lettera } & \text { Gràfila } & \text { SAC } & \text { Obtenido de }\end{array}$ http://repositorio.pucp.edu.pe/index/bitstream/handle/123456789/53194/Libro\%20Finlandia.pdf?sequence=1\&is Allowed=y

Salazar, J. (2018). Evaluación de Aprendizaje Significativo y Estilos de aprendizaje: Alcances, propuesta y desafíos en el aula, Universidad de la Frontera Chile. Obtenido de https://repositorio.uam.es/bitstream/handle/10486/680830/TP_31_4.pdf?sequence=1\&isAllowed=y

Saldarriega, P., Bravo, G., \& Loor, M. (2016). La teoría constructivista de Jean Piaget y su significación para la pedagogía contemporáne, Universidad Laica Eloy Alfaro de Manabí, Manta, Ecuador. Cientifica, 2(esp), 127-137. Obtenido de https://dialnet.unirioja.es > descarga > articulo

Sanchez, P. K. M., Lopez, C. G. N., Lopez, M. M. L., \& Figueroa, Y. G. M. (2019). Learning problems: pedagogical intervention. International Research Journal of Engineering, IT \& Scientific Research, 5(6), 25-32. https://doi.org/10.21744/irjeis.v5n6.806 
Solorzano, F., \& García, A. (2014). Fundamentos del aprendizaje en red desde el conectivismo y la teoria de la actividad. Scielo, 35(3), 1-15. Obtenido de http://scielo.sld.cu/scielo.php?script=sci_arttext\&pid=S025743142016000300008

Tama, F., \& Brooks III, C. L. (2002). The mechanism and pathway of pH induced swelling in cowpea chlorotic mottle virus. Journal of molecular biology, 318(3), 733-747. https://doi.org/10.1016/S0022-2836(02)00135-3

Tinoco, W., \& Tinoco, N. (2017). La didáctica como erramienta para el desarrollo de habilidades en la educación basica,Universidad Técnica de Machala, Ecuador. Dialnet, 14(43), 157-165. Obtenido de https://dialnet.unirioja.es/servlet/articulo?codigo $=6210799$

Vivas, BN (2015). Las inteligencias multiples como estrategias didàcticas para atender a diversidad y aprovechar el potencial de todos los alumnos. Revista nacional e internacional de educaciòn inclusiva, 8(3), 121-136. Obtenido de https://dialnet.unirioja.es > servlet > articulo

Sanchez, PKM, Pazmino, MF, \& Gamez, MR (2020). Prezi as an innovative teaching tool for the strengthening of significant learning. International Research Journal of Management, IT and Social Sciences, 7 (1), $72-83$. https://doi.org/10.21744/irjmis.v7n1.825 